\title{
Effects of Natural Diet on Growth on White-Leg Shrimp Litopenaeus vannamei Under Experimental Mesocosms Emulating an Intensive Culture System
}

\author{
Bojórquez-Mascareño El ${ }^{1}$ and Soto-Jiménez MF*
}

${ }^{1}$ Posgrado en Ciencias del Mar y Limnología, Universidad Nacional Autónoma de México, Unidad Académica Mazatlán, Mexico

¿Unidad Académica Mazatlán, Instituto de Ciencias del Mar y Limnología, Universidad Nacional Autónoma de México (UAM-ICMyL-UNAM), México

\begin{abstract}
A study of nitrogen $(\mathrm{N})$ balance and stable isotopes was conducted to assess the impact of natural diet on white leg shrimp (Litopenaeus vannamei) under experimental mesocosms emulating an intensive culture system. We tested isonitrogenous diets by using commercial formulated feed (FF), natural food (NF) produced in the column water $(\mathrm{FF}+\mathrm{NF})$ and sediments $(\mathrm{FF}+\mathrm{NF}+\mathrm{S})$ on earth ponds, and combinations 50:50 ratio based on $\mathrm{N}$ content. A followed study was conducted in three representative ponds at farm level. Specimens were tested for gain of weight, survival rate, specific growth rate (SGR) and parameters $\mathrm{k}$ and $\mathrm{m}$ and $\mathrm{t}_{50}$ in four trials, from post-larvae of twenty days (PL-20's) to larger juveniles. Specimens raised on FF+NF+S and FF+NF treatments showed weight, SGR's and survival significantly higher than shrimp raised on pure diets (FF and NF) and in ponds at the same time $(p<0.05)$ Exceptions were observed for the larger shrimp (trial 4) with no significant differences. Feed conversion ratios (FCR) in organisms reared on combined diets were lower than FF diet. Based on isotope mixing model the relative contribution of the natural productivity varied among combined diets and trials. N contributions to growth of PL-20's specimens were $18-74 \%$ for $\mathrm{FF}+\mathrm{NF}$ and $25-62 \%$ for $\mathrm{FF}+\mathrm{NF}+\mathrm{S}$ treatments, decreasing with the shrimp size to $<10 \%$ in largest juveniles. Comparable results were observed in ponds. Extrapolating our results to a farm level, farmers may be able to reduce FCRs and improve profitability by enhancing the natural productivity during the first weeks of an intensive shrimp farm culture. Stable isotopes of $\mathrm{N}$ were useful to assess changes in the isotopic signals of shrimp fed with different diets and thus, to determine the $\mathrm{N}$ source for shrimp growth.
\end{abstract}

Keywords: Stables isotopes; Shrimp farm; Formulated food; Specific growth rate

\section{Introduction}

Numerous studies have reported that pond primary productivity can contribute to shrimp nutrition [1-7]. Benefits of natural diet includes sustainability of nutritional requirements during post larval and juvenile stages shortly after the stocking of the ponds, reduction of mortality in post-larvae and increases of growth rates in shrimp farm ponds. In fact, benefits of the natural productivity have been reported for different production systems of shrimp farm, including extensive [1], semi-intensive [7-9], intensive and hyper-intensive systems [10-12]. Contribution of the natural production varied among different culture systems (higher for extensive and lower for hyper-intensives) and shrimp species. Considering these reports an adequate management of the pond enhancing the natural production would elevate the availability of high quality food for shrimp, reducing operation costs and minimizing environmental impact [13-15], which is paramount for the success and sustainability of any commercial shrimp farming operation [16]. Although studies have reported the multiple benefits of natural food in shrimp farm ponds [1,17-20], is it difficult to quantify at the farm level exactly to what extent it does so. In addition, it is difficult to make comparison among a large number of research reports published because different strategies and methodologies were followed. Most of the studies have been conducted in clear water tank systems or in laboratory under controlled conditions, thus the contributions of natural foods has not been evaluated, making it difficult to extrapolate to culture systems. Stable isotopes analysis (SIA) has emerged as an important tool for addressing questions of changes in the isotopic composition of tissues after a change in diet. This application takes advantage of natural variations in stable isotopes ratios, which result from the chemical or biological processes that cause isotopic discrimination or fractionation. The use of natural nitrogen stable isotope analysis (e.g., $\delta^{15} \mathrm{~N}$, which is the ratio of ${ }^{15} \mathrm{~N}$ to ${ }^{14} \mathrm{~N}$ relative to a reference standard) has been valuable to detect diet turnover rates, to examine the better assimilation of diets and to evaluate the relative contributions of isotopically distinct diets [1,21-24]. We conducted a multiple controlled experiments to evaluate the contribution of natural food production to shrimp growth in an intensive culture system. Our study was carried out in the shrimp farm facilities, the nearest to get the field conditions, but the advantage of the possibility to replicate. Our mesocosms diet-shift study was designed considering pond management practice and feeding scenarios in a typical intensive shrimp farm from the Gulf of California coastal zone. This culture type is based on $100 \%$ commercial formulated food, but with the potential to enhance the natural productivity in earth ponds. We run a series of growth trials with post-larvae and different size-classes of white shrimp Litopenaeus vannamei (juveniles from $<1$ to 6-7 g) along with observations in shrimp farm ponds. Based on the analysis of factors regulating the growth

*Corresponding author: Soto-Jiménez MF, Unidad Académica Mazatlán, Instituto de Ciencias del Mar y Limnología, Universidad Nacional Autónoma de México, México, Tel: +52 (669) 9852845 to 48; Fax: +52 (669) 9826133; E-mail:martin@ola.icmyl.unam.mx

Received August 13, 2012; Accepted November 21, 2012; Published November 30, 2012

Citation: Bojórquez-Mascareño El, Soto-Jiménez MF (2013) Effects of Natura Diet on Growth on White-Leg Shrimp Litopenaeus vannamei Under Experimental Mesocosms Emulating an Intensive Culture System. J Aquac Res Development 4:163 doi:10.4172/2155-9546.1000163

Copyright: (c) 2013 Bojórquez-Mascareño El, et al. This is an open-access article distributed under the terms of the Creative Commons Attribution License, which permits unrestricted use, distribution, and reproduction in any medium, provided the original author and source are credited. 
Citation: Bojórquez-Mascareño El, Soto-Jiménez MF (2013) Effects of Natural Diet on Growth on White-Leg Shrimp Litopenaeus vannamei Under Experimental Mesocosms Emulating an Intensive Culture System. J Aquac Res Development 4:163 doi:10.4172/2155-9546.1000163

Page 2 of 9

rates and performance of animals (e.g., survival, weight, feed conversion ratio, and growth rates), and by using SIA we determined the relative importance of natural diet and its contribution to the shrimp biomass.

\section{Material and Methods}

The mesocosm experiments were conducted in a commercial shrimp farm located on the Northwest coast of Mexico (Aquastrat S. A. de C. V. in Teacapán, Sinaloa; $\left.22^{\circ} 40^{\prime} 08^{\prime \prime} N, 105^{\circ} 45^{\prime} 22^{\prime \prime}\right)$. Aquastrat is a shrimp farm with intensive cultivation system with two annual cycles (Summer-Autumn and Spring-Summer). The management practices in the farm (stocking densities, feeding strategies, water exchange rates, water quality parameters, etc.) were monitored during one cycle previous to run trials (Summer-Autumn 2008). First of all, the ponds are filled with seawater from Teacapán bay and immediately fertilized with inorganic fertilizer (urea containing $46 \% \mathrm{~N}$ and single super phosphate containing $16 \% \mathrm{P}_{2} \mathrm{O}_{5}$ ) to improve the natural productivity of the pond. In order to "mature" the pond, commercial feed was added (FR at $100 \%$ of the initial biomass) one week before stocking. The stocking density in the farm is 60 PL's per $\mathrm{m}^{2}$. Farmers typically follow a feeding table to calculate the feeding rates (FR) based on survival rate, expected feed conversion ratio (FCR), and predicted biomass over a given period. Each week FR is adjusted based on food consumption in feeding trays and biometric analysis. Large variations in FR occurred along culture cycle, mostly following a feeding pattern. During the first 4-5 weeks the post larvae are fed with formulate feed (crumble and starter with $40 \%$ of protein) in ratios from $100 \%$ (week 1), $30-40 \%$ (week 2-3) to 10\% (week 4-5) of the biomass. During the following 4550 days (week 7 to 14-15) the feed are dried pellets with 35\% protein. The FR is $3-10 \%$ (geometric media of $6 \%$ ) of the body weight. During the last 5-6 weeks of the cycle, shrimp are fed with FF with $30 \%$ proteins in rates of $5-7 \%$ of the body weight. Feed is supplied mostly by volley from a movement vehicle in three ratios per day: $25 \%$ in the morning and afternoon and 50\% in the evening. Exchange water rates (EWR) in the ponds increased from $0 \%$ to $30 \% \mathrm{~d}^{-1}$. At the beginning, the seawater pumping to the ponds was only to keep the levels lost by infiltration and evaporation ( $0-10 \%$ per day). After week 3 the EWR increased from $10-15 \% \mathrm{~d}^{-1}$ to a maximum of $30 \%$ of week $6-8$ onward. Besides, the availability of natural feed and the growth of shrimp at farm level were evaluated in three representative ponds of Aquastrat during two cycles (Summer-Autumn 2008 and Spring-Summer 2009). Different component of natural foods were identified in our study, including phytoplankton, zooplankton, zoobenthos, bioflocs, and detritus. Microscopic analysis of zooplankton, collected with a mesh from 300 to 500 microns, revealed the presence of a large variety of potential food items for shrimp including copepods, amphipods, diatoms and larvae of bivalves, polychaetes and other crustaceans, and some detritus. Detritus collected by syphoning surface sediments revealed the presence of non-eaten particles of artificial feed, organic matter remains, microphytobenthos and meiofauna constituted by nematodes, polychaetes and Harpacticoid copepods. It was observed that two types of bioflocs were developed few days after starting the experiments; first a green algal-based floc attached to the tank wall (algal-floc) and then particulate matter aggregates (microbial-floc) associated to detritus. Experimental mesocosms and a followed study in shrimp farm ponds were conducted during the Spring-Summer 2009 cycle. Four trials represented different life stages of shrimp: postlarvae, smaller, medium and larger juveniles. In this study, we tested isonitrogenous (35-40\% protein) diets by using natural food (NF) and commercial formulated feed (FF) under four treatments: 1) artificial feed (FF), 2) natural feed (NF), 3) combination 50:50 ratio based on the $\mathrm{N}$ content enhancing the natural food potentially produced in the water column (plankton+bioflocs, FF+NF), and 4) similar to 3 but with sediments enhancing the natural food potentially produced in earthen ponds (plankton+bioflocs+benthos, $\mathrm{FF}+\mathrm{NF}+\mathrm{S}$ ). The experiments on trials 1-4 were conducted in 9 circular tanks $\left(0.5 \mathrm{~m}^{2}\right.$ bottom surface area, $400 \mathrm{~L}$ water volume) set up adjacent to the shrimp farm. White shrimp postlarvae and juveniles were directly obtained from three selected ponds from this shrimp farm and acclimated for one week before each trial. During this time the organisms were fed with commercial feed, the same as the ones in ponds. After acclimation, specimens were separated and randomly distributed into tanks. Three tanks were randomly selected for each one of the four treatments, including natural feed (NF), formulated feed (FF) and combination with natural feed of both 50:50 ratio based on the $\mathrm{N}$ content without $(\mathrm{NF}+\mathrm{FF})$ and with $(\mathrm{NF}+\mathrm{FF}+\mathrm{S})$ sediments. Shrimp farm ponds and treatment tanks were supplied with seawater from Bay Teacapán at ambient temperature and with natural daylight. Sediments were collected directly from earth ponds and added to the tanks without treatment to warranty that living benthic organisms were also introduced. Tanks were covered with a shade net to prevent excessive heating. Air stones connected to a regenerative blower were placed to ensure proper aeration and mixing of the water. For the first trial, a total of 100 postlarvae with a total length of $12.0-18.0 \mathrm{~mm}$ and an average weight of $51.7 \pm 7 \mathrm{mg}$ were stocked in each experimental tank. The FF used was crumble $(<0.5$ $\mathrm{mm}$ ) with $40 \%$ protein (wet weight, Table 1). FR was $30-40 \%$ of biomass and WER of $0 \% \mathrm{~d}^{-1}$, only with reposition of evaporated water $\left(<3 \% \mathrm{~d}^{-1}\right)$. In the second trial, 30 L. vannamei small juveniles (initial weight, 0.251 $\pm 0.105 \mathrm{~g}$ ) were stocked into each tank to test the four treatments for 4

\begin{tabular}{|c|c|c|c|c|c|c|}
\hline Diet component & $\delta^{15} \mathrm{~N}$ & $\delta^{13} \mathrm{C}$ & $\mathrm{mg} \mathrm{N} \mathrm{g}^{-1}$ & $\mathrm{mg} \mathrm{C} \mathrm{g}^{-1}$ & C:N & Trial \\
\hline \multicolumn{7}{|c|}{${ }^{1}$ Natural feed } \\
\hline Phytoplankton & $6.88 \pm 0.09$ & $-21.59 \pm 0.03$ & $39.8 \pm 0.74$ & $214 \pm 1.1$ & $6.27 \pm 0.2$ & 1 \\
\hline Zooplankton & $11.2 \pm 0.11$ & $-20.62 \pm 0.73$ & $61.6 \pm 0.4$ & $245 \pm 2.7$ & $4.65 \pm 0.2$ & $1-3$ \\
\hline Algal-flocs & $6.70 \pm 0.04$ & $-22.59 \pm 0.10$ & $42.3 \pm 0.53$ & $207.1 \pm 0.54$ & $5.7 \pm 0.06$ & $1-4$ \\
\hline Micro-flocs & $4.81 \pm 0.50$ & $-22.64 \pm 0.66$ & $75.4 \pm 27.0$ & $271 \pm 48.4$ & $7.65 \pm 1.9$ & $1-4$ \\
\hline${ }^{2}$ Detritus & $4.83 \pm 0.57$ & $-25.08 \pm 0.90$ & $2.03 \pm 0.98$ & $21.6 \pm 12.9$ & $11.76 \pm 2.2$ & $1-3$ \\
\hline \multicolumn{7}{|c|}{${ }^{3}$ Formulated feeds } \\
\hline Crumble $40 \%$ & $6.45 \pm 0.20$ & $-22.91 \pm 0.15$ & $80.5 \pm 0.03$ & $521 \pm 50$ & $7.6 \pm 0.22$ & 1 \\
\hline Micropellets 40\% & $4.82 \pm 0.26$ & $-23.95 \pm 0.24$ & $64.7 \pm 5.98$ & $459 \pm 10$ & $8.32 \pm 0.5$ & 2 \\
\hline Pellet 35\% & $5.80 \pm 0.13$ & $-23.97 \pm 0.17$ & $67.9 \pm 11.5$ & $494 \pm 63$ & $8.51 \pm 0.3$ & 3,4 \\
\hline
\end{tabular}

${ }^{1}$ Natural diet components (\% dry weight): Protein content: $35-40 \%$, fats 6-7\%, Crude fiber: $8.6-9 \%$, Nitrogen-Free Extract (NFE) $30-46 \%$, ${ }^{2}$ Detritus: Protein content: $13-17 \%$, fats 3-4\%, crude fiber: $7.5-9.2 \%$, and NFE (including ash): $60-70 \%$. ${ }^{3}$ Different formulated feed used in intensive shrimp culture: Protein content: $40-45 \%$ (indicated), fats 8-9\%, crude fiber: $3.5-4.5 \%$, and NFE: $42-48 \%$. Facts as reported on labels.

Table 1: Contents and isotopic composition of $\mathrm{C}$ and $\mathrm{N}$, and $\mathrm{C}: \mathrm{N}$ of each diet component For $L$. vannamei reared on four different treatments from $\mathrm{PL}$ to larger juveniles (trials 1 to 4$)$. 
Citation: Bojórquez-Mascareño El, Soto-Jiménez MF (2013) Effects of Natural Diet on Growth on White-Leg Shrimp Litopenaeus vannamei Under Experimental Mesocosms Emulating an Intensive Culture System. J Aquac Res Development 4:163 doi:10.4172/2155-9546.1000163

weeks. FR was $10 \%$ and the WER of $15-20 \% \mathrm{~d}^{-1}$. We used commercial feed starter pelletized (micropellets $0.5-0.1 \mathrm{~mm}$ ) with $40 \%$ protein. Crumbles and starter are small-particle-size feeds recommended from stocking to $\sim 1 \mathrm{~g}$ and then from $>1 \mathrm{~g}$ (0-15 days) to 3-4 g average body weight, respectively. According to the manufacturer, they are highly digestible and contain all nutrients required by shrimp on the early developmental stages. For the third and fourth trials, the protocol was a repetition of trial 2 , but using 30 and 24 specimens with an initial weight of $2.79 \pm 0.26 \mathrm{~g}$ and $6.21 \pm 0.72 \mathrm{~g}$, respectively. Organisms were fed with pellets $(1.5-2.5 \mathrm{~mm})$ with $35 \%$ protein (Table 1$)$. Pellets are used during the stage of juvenile exponential growth (3-8 g, day 30-60 $\mathrm{d}$ onward). The FR was $10 \%$ and the WER of $15-20 \% \mathrm{~d}^{-1}$ for trial 3 , and $7 \%$ and $30 \%$, respectively, for trial 4 . Rations were divided in three portions (25\% in the morning and afternoon and $50 \%$ in the evening) and supplied in such a way that the food was clearly visible by using feeding trays. During the experiment, FR was progressively adjusted on a weekly basis in relation to the biomass observed, similarly to the procedure in the farm ponds. The amount of feed supplied to each tank was recorded. Commercial shrimp feeds (FF) by Vimifos were used in our experiments (Table 1). Proximal composition (\% dry weight) of the formulated feed varied from $42-45 \%$ (crumble and starter micropellets) and $38-40 \%$ (1.5-2.5 mm pellets) protein, $8-9 \%$ of lipids, $3.5-4.5 \%$ crude fiber, and $42-48 \%$ as nitrogen-free extract (NFE). Component of natural foods were collected directly from ponds and treatment tanks. Proximal composition (\% dry weight) varies among different types of natural feed with contents from $35-40 \%$ protein, $6-7 \%$ lipids, $8.6-9 \%$ crude fiber, and $30-46 \%$ NFE. Analysis of etritus revealed low protein content (13-17\%) and fats (3-4\%), but high content of crude fiber (7.5-9.2\%) and NFE content (60-70\%, including ash) (Table 1). Sludge accumulated in the tank as a result of deposition of waste products from feeding and other detritus was removed daily via a central drain and wall tanks in treatment FF were manually cleaned using a mop to prevent the accumulation of organic rich bio films. In order to minimize the risk of bacterial and viral infection, all the material was carefully disinfected by using chloride solution, which was rinsed with abundant water. Molting and survival were observed daily, and molts and dead specimens were removed from each tank.

\section{Data and sample collection}

At the beginning of the experiments, 10 individuals were randomly collected for analysis of the biometric characteristics, health condition and for analysis of $\mathrm{C}$ and $\mathrm{N}$ stables isotopes. At the end of the experiment shrimp were harvested, counted and specimens from the same treatment were analyzed for biometric characteristics. The weight (W) was measured in a semi-analytical scale $( \pm 0.1 \mathrm{mg})$ and total length (TL) was measured stereomicroscopically using a micrometer to 0.01 $\mathrm{mm}$ and using a Vernier scale for juveniles. Shrimp specimens were dissected to separate the muscle. In total, tissues from 9 individuals from each treatment were selected for isotopes analysis (3 per replicated tank). At the end the experiment only the largest specimens were collected for SIA because we assumed they were the best acclimatized during the experiment. Due the natural variability in the isotopic signatures in natural diet components could vary among batches, we prepared a homogeneous mixture of samples collected for several days. For the formulated diet treatments we used three different commercial aquaculture feeds by Vimifos, which are applied in the shrimp farm during different stages of culture (Table 1), including (PL20's and smaller juvenile fed with crumble and starter, $40 \%$ protein respectively and larger juvenile fed with shrimp food, $35 \%$ protein). No other food was available to the shrimp. All samples and diet components were frozen and freeze-dried for 72 hours. The dried samples were ground, homogenized, and stored in sealed polypropylene containers until analysis. Dried, ground and homogenized samples were placed in a glass chamber vaporized with concentrated $\mathrm{HCl}(4 \mathrm{~h})$ in order to remove carbonates, dried at $60^{\circ} \mathrm{C}(4 \mathrm{~h})$ and stored at $4^{\circ} \mathrm{C}$. Lipids were not removed from our samples prior to analysis. Aliquots of $1.0 \pm 0.1$ $\mathrm{mg}$ were weighed into $5 \times 3.5 \mathrm{~mm}$ tin capsules. Encapsulated samples were analyzed at the Department of Plant Science of The University of California at Davis, CA, USA, in a PDZ Europa Scientific Roboprep elemental analyzer coupled to a PDZ Europa Hydra 20/20 stable isotope ratio mass spectrometer (IRMS). Samples were analyzed for carbon and nitrogen contents and isotopic composition. Analytical precision (standard deviation, $\mathrm{n}=5$ ) was $0.2 \%$ for nitrogen and carbon, as estimated from standards (peach leaves NIST-1547 and bovine liver NIST-1577b, from National Institute of Standard Technology) analyzed every 12 samples. The isotopic composition $\left(\delta^{15} \mathrm{~N}\right)$ in per mil $(\% 0)$ was expressed as the relative difference between isotopic ratios in the sample and in conventional standards (atmospheric $\mathrm{N}_{2}$ for nitrogen):

\section{$\delta^{15} \mathrm{~N}=[(\mathrm{R}$ sample/R standard $)-1] 1000$, where $\mathrm{R}$ is ${ }^{15} \mathrm{~N} /{ }^{14} \mathrm{~N}$}

Critical parameters, including dissolved oxygen, temperature, $\mathrm{pH}$ and salinity were daily monitored 3 times per day with a YSI 5775 sonde and recorded throughout the experimental periods. Water samples were collected from each tank once a week and at the end of the experiments for nutrient analysis. Suspended particulate matter (SPM) was collected by filtering 200-1000 $\mathrm{ml}$ of the water samples through a pre-combusted $\left(500^{\circ} \mathrm{C}, 4 \mathrm{hr}\right)$ glass fiber filter $(\mathrm{GF} / \mathrm{F})$ with a low-pressure vacuum pump. The particulates on the filters $(>0.45 \mu \mathrm{m})$ were air-dried at 55 $60^{\circ} \mathrm{C}$. Total SPM was determined by comparing filter weights before and after filtration of a known amount of water. Duplicate water samples were filtered and frozen immediately at $-20^{\circ} \mathrm{C}$. Chlorophyll a (Chl a) was extracted from frozen SPM with the addition of acetone, mechanical grinding, centrifuging and then supernatant was analyzed in a spectrophotometer [25]. Analysis of total ammonia (TAN) was analyzed by Phenol hypochlorite method [26], nitrate reduced to nitrite by passing the sample through a copperized cadmium column and then the reduced nitrate and original nitrite were determined by diazotizing with sulfanilamide followed by coupling with $\mathrm{N}$-(1-naphthyl) ethylenediamine dihydrochloride [26]. Total dissolved N (TDN) was analyzed by converting all $\mathrm{N}$ into nitrate by alkaline persulfate oxidation, and particulated organic $\mathrm{N}$ (PON) was analyzed by elemental analyzer coupled to IRMS. Total N was obtained as the sum of TDN and PON. Calculations of the growth indexes and survival rates of the shrimps in the multiple treatments and were done. By using the biometric and counting data. Biomass was estimated based on the average weight and total number of specimens. The mean specific growth rate ([SGR $=(\mathrm{Ln}$ Wf-Ln Wi $/(\mathrm{t}) \times 100])$ [18] was calculated for each experimental group. $\mathrm{Wi}$ and $\mathrm{Wf}$ were the averaged weights for the shrimps at the beginning and at the completion of trial time ( $\mathrm{t}$ ), respectively. Besides, the ratios of food conversion ratio (FCR=Total feed consumed $(\mathrm{kg}) /$ total yield $(\mathrm{kg})$ ) were also calculated $[18,27]$. An exponential model $[23,28]$ was used to estimate the proportions of changes in tissue isotopic composition over time, which are due to metabolic turnover. In the model that integrates growth and isotope shifts over time, it is assumed that any isotopic change in shrimp tissues following a change in diet is due to growth and/or metabolic turnover. This model provides an estimate of the elemental $\mathrm{N}$ turnover rate in shrimp and its effect on isotopic change:

$$
\delta^{15} \mathrm{~N}_{\mathrm{t}}=\delta^{15} \mathrm{~N}_{\mathrm{f}}+\left(\delta^{15} \mathrm{~N}_{\mathrm{i}}-\delta^{15} \mathrm{~N}_{\mathrm{f}}\right) \mathrm{e}^{-(\mathrm{k}+\mathrm{m}) \mathrm{t}}
$$

where $\delta^{15} \mathrm{~N}_{\mathrm{t}}$ is the shrimp tissue isotope value at time $\mathrm{t}, \delta^{15} \mathrm{~N}_{\mathrm{i}}$ is the initial 
Citation: Bojórquez-Mascareño El, Soto-Jiménez MF (2013) Effects of Natural Diet on Growth on White-Leg Shrimp Litopenaeus vannamei Under Experimental Mesocosms Emulating an Intensive Culture System. J Aquac Res Development 4:163 doi:10.4172/2155-9546.1000163

Page 4 of 9

\begin{tabular}{|c|c|c|c|c|c|c|}
\hline Analite & Initial & NF & FF & $N F+F F$ & $\mathrm{NF}+\mathrm{FF}+\mathrm{S}$ & Farm ponds \\
\hline \multicolumn{7}{|l|}{ Trial 1} \\
\hline $\mathrm{NH}_{4}+\left(\mu \mathrm{L} \mathrm{L}^{-1}\right)$ & $9.59 \pm 0.01$ & $24.8 \pm 1.38$ & $28.4 \pm 27.4$ & $12.5 \pm 2.44$ & $28.4 \pm 27.4$ & $25.8 \pm 9.84$ \\
\hline $\mathrm{NO}_{2}-\left(\mu \mathrm{g} \mathrm{L}^{-1}\right)$ & $0.15 \pm 0.01$ & $0.09 \pm 0.05$ & $0.09 \pm 0.04$ & $0.12 \pm 0.09$ & $0.09 \pm 0.04$ & $0.17 \pm 0.08$ \\
\hline $\mathrm{NO}_{3}-\left(\mu \mathrm{LL}^{-1}\right)$ & $17.5 \pm 0.01$ & $18.9 \pm 4.38$ & $16.0 \pm 2.57$ & $25.5 \pm 19.3$ & $16.0 \pm 2.57$ & $9.56 \pm 6.65$ \\
\hline $\mathrm{NT}\left(\mathrm{mg} \mathrm{L}^{-1}\right)$ & $2.4 \pm 0.00$ & $0.70 \pm 0.19$ & $1.26 \pm 0.49$ & $0.62 \pm 0.12$ & $1.26 \pm 0.49$ & $1.03 \pm 0.04$ \\
\hline Chl-a $\left(\mathrm{mg} \mathrm{m}^{-3}\right)$ & $3.64 \pm 1.62$ & $31.1 \pm 22.7$ & $134 \pm 75.8$ & $32.9 \pm 13.2$ & $134 \pm 75.9$ & $5.13 \pm 1.33$ \\
\hline $\mathrm{SST}\left(\mathrm{mg} \mathrm{L}^{-1}\right)$ & $27.1 \pm 0.01$ & $29.6 \pm 0.24$ & $70.3 \pm 18.0$ & $85.2 \pm 21.0$ & $70.3 \pm 18.0$ & $40.0 \pm 6.11$ \\
\hline $\mathrm{T}\left({ }^{\circ} \mathrm{C}\right)$ & $22.3 \pm 0.60$ & $22.5 \pm 0.87$ & $23.2 \pm 0.57$ & $22.5 \pm 0.87$ & $23.2 \pm 0.57$ & $26.8 \pm 0.19$ \\
\hline $\mathrm{OD}\left(\mathrm{mg} \mathrm{L}^{-1}\right)$ & $7.43 \pm 0.21$ & $7.03 \pm 0.21$ & $7.07 \pm 0.06$ & $7.03 \pm 0.21$ & $7.07 \pm 0.06$ & $7.02 \pm 0.07$ \\
\hline \multicolumn{7}{|l|}{ Trial 2} \\
\hline $\mathrm{NH}_{4}+\left(\mu \mathrm{g} \mathrm{L}^{-1}\right)$ & $17.0 \pm 3.53$ & $16.7 \pm 5.50$ & $82.1 \pm 17.4$ & $35.2 \pm 24.7$ & $70.5 \pm 2.54$ & $13.2 \pm 9.35$ \\
\hline $\mathrm{NO}_{2}-\left(\mu \mathrm{g} \mathrm{L}^{-1}\right)$ & $0.06 \pm 0.01$ & $0.34 \pm 0.01$ & $0.36 \pm 0.13$ & $0.21 \pm 0.03$ & $0.32 \pm 0.13$ & $0.19 \pm 0.02$ \\
\hline $\mathrm{NO}_{3}-\left(\mu \mathrm{L} \mathrm{L}^{-1}\right)$ & $9.03 \pm 2.7$ & $12.1 \pm 1.61$ & $9.86 \pm 0.45$ & $9.08 \pm 2.39$ & $8.16 \pm 2.84$ & $15.7 \pm 9.82$ \\
\hline NT $\left(\mathrm{mg} \mathrm{L}^{-1}\right)$ & $0.84 \pm 0.15$ & $1.81 \pm 0.46$ & $1.70 \pm 0.51$ & $1.73 \pm 0.16$ & $1.91 \pm 0.41$ & $1.48 \pm 0.16$ \\
\hline $\mathrm{Chl}-\mathrm{a}\left(\mathrm{mg} \mathrm{m}^{-3}\right)$ & $8.03 \pm 3.71$ & $6.19 \pm 1.11$ & $115 \pm 16.9$ & $96.8 \pm 66.5$ & $208 \pm 119$ & $15.9 \pm 6.00$ \\
\hline $\mathrm{SST}(\mathrm{m}$ & $24.6 \pm 3.04$ & $43.5 \pm 1.18$ & $83.9 \pm 5.95$ & $57.8 \pm 14.1$ & $80.3 \pm 28.2$ & $100 \pm 18.7$ \\
\hline $\mathrm{T}\left({ }^{\circ} \mathrm{C}\right)$ & $24.4 \pm 0.08$ & $25.1 \pm 0.46$ & $24.8 \pm 0.37$ & $25.2 \pm 0.46$ & $24.9 \pm 0.23$ & $28.5 \pm 0.13$ \\
\hline $\mathrm{OD}(\mathrm{mg}$ & $7.00 \pm 0.01$ & $6.35 \pm 0.08$ & $6.33 \pm 0.08$ & $6.33 \pm 0.08$ & $6.43 \pm 0.12$ & $7.14 \pm 0.39$ \\
\hline \multicolumn{7}{|l|}{ Trial 3} \\
\hline $\mathrm{NH}_{4}+\left(\mu \mathrm{g} \mathrm{L}^{-1}\right)$ & $8.49 \pm 0.37$ & $115 \pm 54.8$ & $468 \pm 13.4$ & $251 \pm 33.4$ & $260 \pm 13.0$ & $32.3 \pm 27.8$ \\
\hline $\mathrm{NO}_{2}-\left(\mu \mathrm{g} \mathrm{L}^{-1}\right)$ & $0.03 \pm 0.01$ & $1.05 \pm 0.25$ & $1.21 \pm 0.46$ & $1.35 \pm 0.51$ & $1.21 \pm 0.12$ & $0.13 \pm 0.02$ \\
\hline $\mathrm{NO}_{3}-\left(\mu \mathrm{LL}^{-1}\right)$ & $20.5 \pm 1.14$ & $19.6 \pm 5.46$ & $28.4 \pm 20.3$ & $32.1 \pm 4.26$ & $23.1 \pm 3.31$ & $5.12 \pm 2.89$ \\
\hline $\mathrm{NT}\left(\mathrm{mg} \mathrm{L}^{-1}\right)$ & $0.94 \pm 0.03$ & $2.65 \pm 0.87$ & $2.47 \pm 2.05$ & $2.40 \pm 0.60$ & $3.2 \pm 0.6$ & $1.64 \pm 0.46$ \\
\hline Chl-a $\left(\mathrm{mg} \mathrm{m}^{-3}\right)$ & $21.5 \pm 6.51$ & $94.4 \pm 25.3$ & $57.8 \pm 37.7$ & $53.0 \pm 23.8$ & $108 \pm 43$ & $45.1 \pm 8.70$ \\
\hline $\mathrm{SST}\left(\mathrm{mg} \mathrm{L}^{-1}\right)$ & $16.1 \pm 1.08$ & $56.2 \pm 2.83$ & $184 \pm 32.2$ & $108 \pm 24.8$ & $205 \pm 32.2$ & $142 \pm 35.1$ \\
\hline $\mathrm{T}\left({ }^{\circ} \mathrm{C}\right)$ & $24.4 \pm 0.58$ & $26.7 \pm 0.60$ & $25.7 \pm 0.63$ & $26.7 \pm 0.60$ & $26.0 \pm 0.40$ & $27.5 \pm 0.42$ \\
\hline $\mathrm{OD}\left(\mathrm{mg} \mathrm{L}^{-1}\right)$ & $6.29 \pm 0.13$ & $6.97 \pm 0.10$ & $6.50 \pm 0.18$ & $6.97 \pm 0.10$ & $6.70 \pm 0.13$ & $6.5 \pm 0.23$ \\
\hline \multicolumn{7}{|l|}{ Trial 4} \\
\hline $\mathrm{NH}_{4}+\left(\mu \mathrm{g} \mathrm{L}^{-1}\right)$ & $8.03 \pm 4.0$ & & $118 \pm 121$ & $51.0 \pm 13.6$ & $245 \pm 13.5$ & $19.5 \pm 2.22$ \\
\hline $\mathrm{NO}_{2}-\left(\mu \mathrm{L} \mathrm{L}^{-1}\right)$ & $0.26 \pm 0.01$ & & $4.38 \pm 0.79$ & $4.58 \pm 0.31$ & $4.3 \pm 0.01$ & $0.24 \pm 0.02$ \\
\hline $\mathrm{NO}_{3}-\left(\mu \mathrm{g} \mathrm{L}^{-1}\right)$ & $17.7 \pm 12.7$ & & $1326 \pm 626$ & $1680 \pm 390$ & $894 \pm 412$ & $11.0 \pm 0.64$ \\
\hline $\mathrm{NT}\left(\mathrm{mg} \mathrm{L}^{-1}\right)$ & $1.10 \pm 0.29$ & & $3.17 \pm 0.15$ & $2.59 \pm 0.50$ & $1.8 \pm 0.45$ & $1.54 \pm 0.66$ \\
\hline $\mathrm{Chl}-\mathrm{a}\left(\mathrm{mg} \mathrm{m}^{-3}\right)$ & $14.3 \pm 8.20$ & & $104 \pm 88.8$ & $63.3 \pm 25.3$ & $58.7 \pm 31.0$ & $33.2 \pm 8.55$ \\
\hline $\mathrm{SST}\left(\mathrm{mg} \mathrm{L}^{-1}\right)$ & $26.8 \pm 5.6$ & & $250 \pm 207$ & $71.0 \pm 16.6$ & $141 \pm 52.0$ & $98.8 \pm 22.4$ \\
\hline $\mathrm{T}\left({ }^{\circ} \mathrm{C}\right)$ & $28.2 \pm 1.05$ & & $28.3 \pm 0.42$ & $28.6 \pm 0.29$ & $28.4 \pm 0.15$ & $30.1 \pm 0.28$ \\
\hline $\mathrm{OD}\left(\mathrm{mg} \mathrm{L}^{-1}\right)$ & $7.2 \pm 0.4$ & & $4.77 \pm 0.31$ & $5.27 \pm 0.15$ & $5.10 \pm 0.20$ & $7.02 \pm 1.01$ \\
\hline
\end{tabular}

Table 2: Mean water-quality parameters for each treatment for trials 1 to 4

value before the diet switch, $\delta^{15} \mathrm{~N}_{\mathrm{f}}$ is the final isotopic composition in equilibrium with a new diet, $\mathrm{t}$ is the experiment time (days), $\mathrm{m}$ is the metabolic turnover rate (per day) and $\mathrm{k}$ is the specific growth rate (per day) constant. The constants $\mathrm{m}$ and $\mathrm{k}$ are derived using iterative nonlinear regression and from the exponential growth equation:

\section{$\mathrm{k}=\ln \left(\mathrm{W}_{\mathrm{f}} / \mathrm{W}_{\mathrm{i}}\right) / \mathrm{t}$}

where $\mathrm{W}_{\mathrm{f}}$ and $\mathrm{W}_{\mathrm{i}}$ are the final and initial weight, respectively. In our model, we considered that both growth and metabolic turnover contribute to the pattern of isotopic change $(m>0)$ for animal on growing $(\mathrm{k}>0)$. Half time, defined as the time necessary for half of the body tissue to reach isotopic equilibrium (to be replaced) after consuming a new diet, was calculated using the coefficients $\mathrm{m}$ and $\mathrm{k}\left(\mathrm{t}_{50}=\ln 2 /(\mathrm{m}+\mathrm{k})\right)$. The relative contribution of natural diet to shrimp growth $\left(\mathrm{XNF}=\mathrm{W}_{\mathrm{NF}} /\right.$ $\mathrm{W}_{\mathrm{f}}$ ) was estimated by using the follow equation $[1,24]$ :

$$
\mathrm{W}_{\mathrm{NF}} / \mathrm{W}_{\mathrm{f}}=\left(\delta^{15} \mathrm{~N}_{\mathrm{FF}}-\delta^{15} \mathrm{~N}_{\mathrm{s}-\mathrm{e}}\right) /\left(\delta^{15} \mathrm{~N}_{\mathrm{s}-\mathrm{e}}-\delta^{15} \mathrm{~N}_{\mathrm{NF}}\right)
$$

where $\mathrm{W}_{\mathrm{NF}}$ is the weight gained from $\mathrm{N}_{\mathrm{F}}$ component, Wf is the final weigh and $\delta^{15} \mathrm{~N}_{\mathrm{FF}}$ and $\delta^{15} \mathrm{~N}_{\mathrm{NF}}$ are the isotopic composition of $\mathrm{N}$ for formulated food and natural food, while $\delta^{15} \mathrm{~N}_{\mathrm{se}}$ is the isotopic ratio in shrimp in equilibrium with the new diet. The $\delta^{5-e} \mathrm{~N}_{\mathrm{se}}$ term was obtained from the equation [24]:

$$
\delta^{15} \mathrm{~N}_{\mathrm{s}-\mathrm{e}}=\left(\mathrm{W}_{\mathrm{f}} \delta^{15} \mathrm{~N}_{\mathrm{f}}-\mathrm{W}_{\mathrm{i}} \delta^{15} \mathrm{~N}_{\mathrm{i}}\right) / \mathrm{W}_{\text {gained }}
$$

where $\mathrm{i}$ and $\mathrm{f}$ represent the initial and final values and $\mathrm{W}_{\text {gained }}$ is the weight gained.

The proportionate contribution of $\mathrm{N}$ from each component of the natural diet to the growth of shrimp reared on pure NF diet, was based on a two-source mixing model [22-23,29], as follows:

$$
\begin{aligned}
& \mathrm{X}_{\mathrm{NF} \text { diet1 }}+(1-\mathrm{X}) \mathrm{N}_{\mathrm{F} \mathrm{diet2} 2}=1 \\
& \mathrm{X} \mathrm{NF}_{\text {diet1 }}=1-\left[\left(\delta^{15} \mathrm{~N}_{\mathrm{NF} \text { diet2 }}-\delta^{15} \mathrm{~N}_{\text {shrimp }}+\Delta^{15} \mathrm{~N}\right) /\left(\delta^{15} \mathrm{~N}_{\mathrm{NF} \mathrm{diet1}}-\delta^{15} \mathrm{~N}_{\mathrm{NF} \text { diet2 }}\right)\right]
\end{aligned}
$$

where $\delta^{15} \mathrm{~N}_{\mathrm{NF} \text { diet1 }}$ and $\delta^{15} \mathrm{~N}_{\mathrm{NF} \text { diet2 }}$ are the $\mathrm{N}$ isotope ratios of potential food sources (e.g., plankton and benthos), $\delta^{15} \mathrm{~N}_{\text {shrimp }}$ is the $\mathrm{N}$ isotope ratio of the shrimp at the end of the experiment in NF treatment, and $\Delta^{15} \mathrm{~N}$ is the trophic enrichment for $\mathrm{N}$ experimentally quantified in this study. Nitrogen isotope discrimination factor $\left(\Delta^{15} \mathrm{~N}\right)$ was estimated as the difference between $\delta^{15} \mathrm{~N}$ mean values of shrimps and the $\delta^{15} \mathrm{~N}$ of their respective pure diets after reaching isotopic equilibrium.

\section{Data processing}

The data distribution was evaluated by the Kolmogorov-Smirnoff test for normality. After testing the normality and homogeneity of variances, the growth parameter and isotopic ratios differences among different sizes and diets were compared by ANOVA Tukey's HSD [30]. For statistical analysis, individual shrimp values were averaged for a same treatment ( 3 tanks per treatment and 3 specimens per tank, a total of 9 specimens per group). The level of significance in all statistical tests was 0.05. We used Statistica 7.0 (Statistica for Windows, Statsoft, Tulsa, OK, USA) and Office Excel 2011 (Microsoft Corporation, Redmond,WA, USA) for all the statistical analyses.

\section{Results}

Table 2 summarizes the water-quality parameters observed in treatment tanks and shrimp farm ponds during trials. Overall environmental conditions were satisfactory for shrimp growth, in terms of water temperatures (mean ranging from 22.5 to $28.3^{\circ} \mathrm{C}$ ), salinity (35 to 36$), \mathrm{pH}(8.2$ to 8.4$)$ and DO concentrations (4.8-7.1 $\left.\mathrm{mg} \mathrm{L}^{-1}\right)$ and they did not fall below $4.6 \mathrm{mg} \mathrm{L}^{-1}$. These values were compared, in terms of temperature $\left(25.8\right.$ to $\left.30.1^{\circ} \mathrm{C}\right)$, salinity $(34.5$ 35.5), $\mathrm{pH}(8.1-8.7)$ and $\mathrm{DO}\left(5.4-8.0 \mathrm{mg} \mathrm{L}^{-1}\right)$, to those found in the ponds. A substantial increase as a function of time was observed for SST (from $<30$ to $70-250 \mathrm{mg} \mathrm{L}^{-1}$ ), Chl a (from $<15$ to $30-150 \mu \mathrm{g}$ $\mathrm{L}^{-1}$ ), TN (from $\sim 1$ to $1.7-3.2 \mathrm{mg} \mathrm{L}^{-1}$ ), and chemical forms of $\mathrm{N}$ such $\mathrm{NH} 4+\left(<10\right.$ to $\left.25-245 \mu \mathrm{g} \mathrm{L}^{-1}\right)$ and $\mathrm{NO}_{3}-+\mathrm{NO}_{2}-(<20$ to maximum $>1300$ $\left.\mu \mathrm{g} \mathrm{L}^{-1}\right)$, with final concentrations significantly $(\mathrm{p}<0.05)$ higher than the initial values (Table 2). Concentrations of Chl a, SST, TN and their chemical forms were significantly higher in trials 3 and 4 (juveniles) than trials 1 (PL's). In addition, these quality variables measured were consistently higher in treatment tanks than shrimp ponds $(\mathrm{p}<0.05)$. Salinity, $\mathrm{pH}$, and OD were comparable among experiments and trials, except temperature, which increased gradually with time from $22.3 \pm$ $0.6^{\circ} \mathrm{C}$ (trial 1 in March, 2009) to $28.2 \pm 1.0^{\circ} \mathrm{C}$ (trial 4 in July, 2009). Results of the diet experiments for $L$. vannamei specimens are shown in Tables 3 to 6. No-significant differences were found in growth rates or variance between tanks fed with the same diet (treatment triplicate). Thus, results of shrimp on the same diet were averaged. At the end of trials, a large variability in weight was found among specimens with the same treatment. However, this variability was lower than the observed among treatments. Specimens used for experiments were collected from a same population and similar experimental conditions were kept in each treatment during trials, thus any confounding factors 
Citation: Bojórquez-Mascareño El, Soto-Jiménez MF (2013) Effects of Natural Diet on Growth on White-Leg Shrimp Litopenaeus vannamei Under Experimental Mesocosms Emulating an Intensive Culture System. J Aquac Res Development 4:163 doi:10.4172/2155-9546.1000163

\begin{tabular}{|l|l|l|l|l|l|}
\hline \multicolumn{7}{|c|}{ Treatments } \\
\hline Parameter & Shrimp pond & $\mathrm{NF}$ & $\mathrm{FF}$ & $\mathrm{FF}+\mathrm{NF}$ & $\mathrm{FF}+\mathrm{NF}+\mathrm{S}$ \\
\hline $\begin{array}{l}\text { Mean final } \\
\text { weight }(\mathrm{mg})\end{array}$ & $276 \pm 80^{\mathrm{a}, \mathrm{b}}$ & $243 \pm 40^{\mathrm{a}}$ & $271 \pm 138^{\mathrm{a}, \mathrm{b}}$ & $275 \pm 103^{\mathrm{a}, \mathrm{b}}$ & $317 \pm 67^{\mathrm{b}}$ \\
\hline SGR $\left.\% \mathrm{~d}^{-1}\right)$ & $12-17(15)$ & $12-15(14)$ & $8-19(15)$ & $11-18(15)$ & $14-18(16)$ \\
\hline $\begin{array}{l}\text { Survival rate } \\
(\%)\end{array}$ & $85.7 \pm 3^{\mathrm{a}}$ & $95.0 \pm 2^{\mathrm{b}}$ & $93.3 \pm 2^{\mathrm{b}}$ & $97.8 \pm 1 \mathrm{c}$ & $95.3 \pm 3^{\mathrm{b}, \mathrm{c}}$ \\
\hline $\mathrm{FCR}$ & $0.8-1.0$ & - & $1.3-1.7$ & $0.7-0.8$ & $0.7-0.8$ \\
\hline $\mathrm{k}\left(\mathrm{d}^{-1}\right)$ & $0.15 \pm 0.03^{\mathrm{a}}$ & $0.14 \pm 0.02^{\mathrm{a}}$ & $0.14 \pm 0.05^{\mathrm{a}}$ & $0.15 \pm 0.04^{\mathrm{a}}$ & $0.16 \pm 0.02^{\mathrm{a}}$ \\
\hline $\mathrm{m}\left(\mathrm{d}^{-1}\right)$ & $0.02 \pm 0.01^{\mathrm{a}}$ & $0.017 \pm 0.01^{\mathrm{a}}$ & $0.02 \pm 0.01^{\mathrm{a}}$ & $0.02 \pm 0.01^{\mathrm{a}}$ & $0.024 \pm 0.01^{\mathrm{a}}$ \\
\hline $\mathrm{t} 50(\mathrm{~d})$ & $3.4-5.2(4.0)$ & $4.0-5.0(4.4)$ & $2.6-7.4(4.1)$ & $1.3-5.8(4.0)$ & $3.3-4.3(3.7)$ \\
\hline$\delta^{15} \mathrm{~N}(\%)$ & $8.52 \pm 1.03$ & $12.0 \pm 0.32$ & $8.48 \pm 0.10$ & $8.32 \pm 0.56$ & $8.19 \pm 0.41$ \\
\hline $\begin{array}{l}\text { Relative } \\
\text { contribution (\%) }\end{array}$ & $52-78(66)$ & 100 & - & $18-74(55)$ & $25-62(56)$ \\
\hline
\end{tabular}

Different superscripts indicate significant differences $(a<b<c)$.

Table 3: Mean final weight, specific growth rate (SGR) and growth parameters (m and $k$ ), survival, feed conversion ration (FCR) and natural stable isotope value $\left(\delta^{15} \mathrm{~N}\right)$ for postlarvaes (initial weight $51.7 \pm 7 \mathrm{mg}$ and $\delta^{15} \mathrm{~N}=11.12 \pm 0.26 \%$ ) and estimated $\mathrm{N}$ half time $\left(\mathrm{t}_{50}\right)$ in tissue of shrimp $L$. vannamei reared for 11-days with formulated feed (FF, Crumble 40\%), natural feed (NF) and 50:50 formulated+natural feeds as plankton ( $\mathrm{FF}+\mathrm{NF}$, mixing plankton $\delta^{15} \mathrm{~N}=9.80 \pm 0.76 \%$ ) and plankton+benthos $\left(\mathrm{FF}+\mathrm{NF}+\mathrm{S}, \delta^{15} \mathrm{~N}=4.83 \pm 0.57 \%\right.$ ) (Trial 1). Relative contribution of natural diet to the growth of specimens reared on $\mathrm{FF}+\mathrm{NF}$ and $\mathrm{FF}+\mathrm{NF}+\mathrm{S}$ treatments. Isotopic trophic enrichment $\left(\Delta^{15} \mathrm{~N}=\delta 15 \mathrm{~N}_{\text {shrimp }}-\delta^{15} \mathrm{~N}_{\mathrm{NF}}\right.$ or FF $)$ was estimated in $2.2 \%$ for $\mathrm{NF}$ and $2.03 \%$ for FF.

\begin{tabular}{|l|c|c|c|c|c|}
\hline \multicolumn{5}{|c|}{ Treatments } \\
\hline $\begin{array}{l}\text { Parameter } \\
\text { Mean final } \\
\text { weight (g) }\end{array}$ & $3.3 \pm 0.88^{\mathrm{a}, \mathrm{b}}$ & $2.91 \pm 0.7^{\mathrm{a}}$ & $3.37 \pm 0.8^{\mathrm{a}, \mathrm{b}}$ & $5.02 \pm 0.32^{\mathrm{c}}$ & $5.43 \pm 0.61^{\mathrm{c}}$ \\
\hline SGR & $8-10(9.2)$ & $7-10(8)$ & $9-10(9.5)$ & $10-11(10.5)$ & $11-12(11)$ \\
\hline $\begin{array}{l}\text { Survival rate } \\
(\%)\end{array}$ & $84 \pm 6^{\mathrm{a}}$ & $90 \pm 3^{\mathrm{a}, \mathrm{b}}$ & $96.7 \pm 2^{\mathrm{c}}$ & $90 \pm 4^{\mathrm{a}, \mathrm{b}}$ & $93 \pm 3^{\mathrm{b}, \mathrm{c}}$ \\
\hline FCR & $0.8-1.0$ & - & $1.2-1.5$ & $0.7-1.0$ & $0.7-0.8$ \\
\hline $\mathrm{k}\left(\mathrm{d}^{-1}\right)$ & $0.091 \pm 0.01^{\mathrm{a}, \mathrm{b}}$ & $0.087 \pm 0.01^{\mathrm{a}}$ & $0.09 \pm 0.01^{\mathrm{a}, \mathrm{b}}$ & $0.11 \pm 0.02^{\mathrm{a}, \mathrm{b}}$ & $0.11 \pm 0.00^{\mathrm{b}}$ \\
\hline $\mathrm{m}_{\left(\mathrm{d}^{-1}\right)}$ & $0.11 \pm 0.03^{\mathrm{a}}$ & $0.10 \pm 0.02^{\mathrm{a}}$ & $0.11 \pm 0.03^{\mathrm{a}}$ & $0.17 \pm 0.01^{\mathrm{b}}$ & $0.19 \pm 0.02^{\mathrm{b}}$ \\
\hline $\mathrm{t}_{50}(\mathrm{~d})$ & $2.9-4.4(3.5)$ & $3.2-4.7(3.8)$ & $2.9-4.2(3.4)$ & $2.1-2.8(2.5)$ & $2.2-2.6(2.4)$ \\
\hline$\delta^{15} \mathrm{~N}(\%)$ & $7.43 \pm 0.54$ & $10.13 \pm 0.52$ & $7.31 \pm 0.39$ & $7.74 \pm 0.16$ & $7.45 \pm 0.57$ \\
\hline$\delta^{15} \mathrm{Ng}(\%)$ & $7.35 \pm 0.41$ & $10.30 \pm 0.40$ & $7.22 \pm 0.30$ & $7.70 \pm 0.12$ & $7.40 \pm 0.42$ \\
\hline $\begin{array}{l}\text { Relative } \\
\text { contribution } \\
(\%)\end{array}$ & $6-32(26)$ & 100 & - & $8-22(15)$ & $27-67(31)$ \\
\hline
\end{tabular}

Different superscripts indicate significant differences $(a<b<c)$.

Table 4: Mean final weight, specific growth rate (SGR) and growth parameters ( $m$ and $k$ ), survival, feed conversion ration (FCR), natural stable isotope value $\left(\delta^{15} \mathrm{~N}\right)$ and estimated $\mathrm{N}$ half time $(\mathrm{t} 50)$ in tissue of small shrimp (initial weight, $0.25 \pm 0.10 \mathrm{~g}, \delta^{15} \mathrm{~N}=8.41 \pm 0.1 \%$ o $)$ L. vannamei reared for 28-days with formulated feed (FF, Micropellets 40\%), natural feed (NF) and 50:50 formulated+natural feeds as zooplankton+bioflocs (ס15NNF $=8.83 \pm 0.54 \%$ o $) \quad(F F+N F)$ and plankton+bioflocs+benthos $(\delta 15 N N F=8.13 \pm 1.42 \%)(F F+N F+S)($ Trial 2$)$. Relative contribution of natural diet to the growth of specimens reared on FF+NF and $\mathrm{FF}+\mathrm{NF}+\mathrm{S}$ treatments. Isotopic trophic enrichment $\left(\Delta^{15} \mathrm{~N}=\delta^{15} \mathrm{~N}\right.$ shrimp- $\delta^{15} \mathrm{~N}_{\mathrm{NF}}$ or $\left.\mathrm{FF}\right)$ was estimated in $2.0 \%$ for NF and $2.49 \%$ for FF.

may have influenced the intra-population variability. For the PL stage (Table 3), the averaged final weight (0.243 to $0.317 \mathrm{~g}$ ) and SGR (14$\left.16 \% \mathrm{~d}^{-1}\right)$ reached maximum values in specimens reared on $\mathrm{FF}+\mathrm{NF}+\mathrm{S}$, although these were not significantly different to other treatments and shrimp farm ponds, except for NF $(\mathrm{p}<0.05)$. No-significant differences in survival were found among treatments, which was significantly lower in ponds. Averaged growth parameters $\mathrm{k}\left(0.14-0.16 \mathrm{~d}^{-1}\right)$ and $\mathrm{m}$ (0.017-0.024 $\left.\mathrm{d}^{-1}\right)$, were comparable among treatments and ponds. The time necessary for half of the body tissue to reach isotopic equilibrium after consuming the new diet was also estimated in each treatment. According to the results, $\mathrm{t}_{50}$ varied from 3.7 to $4.4 \mathrm{~d}$ in treatments and from 3.4 to $5.2 \mathrm{~d}$ in ponds. FCR were comparable among treatment $s$ and ponds (0.7-1.0), with the exception of FF (>1.3) treatment. In trial 2 (Table 4 ), the mean final weight (2.91 to $5.43 \mathrm{~g}$ ) and SGR $(8-11 \%$ $\left.\mathrm{d}^{-1}\right)$ were higher for specimens reared on $\mathrm{FF}+\mathrm{NF}$ and $\mathrm{FF}+\mathrm{NF}+\mathrm{S}$ than those on NF and FF treatments and in ponds. Parameters $m(0.10-0.19$ $\left.\mathrm{d}^{-1}\right)$ and $\mathrm{k}\left(0.087-0.11 \mathrm{~d}^{-1}\right)$ were also significantly higher for specimens reared on combined diets compared to pure diets and ponds. Values of t50 averaged from 2.4 to $3.8 \mathrm{~d}$ among treatments and $3.5 \mathrm{~d}$ in ponds. FCR was near or under one, except for FF treatment (1.2-1.5).

In trial 3 (Table 5), the averaged final weight (3.99 to $9.47 \mathrm{~g}$ ), SGR $\left(2-4.4 \% \mathrm{~d}^{-1}\right)$ and growth parameters $\mathrm{m}\left(0.075-0.24 \mathrm{~d}^{-1}\right)$ and $\mathrm{k}(0.019$ $\left.0.044 \mathrm{~d}^{-1}\right)$ showed large variations among treatments. The lowest and highest values were measured in specimens reared on NF and $\mathrm{FF}+\mathrm{NF}$ treatments, respectively. Half time varied from 2.4 to $3.1 \mathrm{~d}$ in treatments

\begin{tabular}{|l|c|c|c|c|c|}
\hline \multicolumn{5}{|c|}{ Treatments } \\
\hline Parameter & Shrimp pond & NF & FF & FF+NF & FF+NF+S \\
\hline $\begin{array}{l}\text { Mean final } \\
\text { weight (g) }\end{array}$ & $7.87 \pm 0.29^{\mathrm{b}}$ & $3.99 \pm 1.8^{\mathrm{a}}$ & $7.66 \pm 0.7^{\mathrm{b}}$ & $9.47 \pm 1.0^{\mathrm{c}}$ & $8.72 \pm 0.31^{\mathrm{b}, \mathrm{c}}$ \\
\hline SGR & $3.5-3.8(3.7)$ & $1-3(2)$ & $3.2-4(3.7)$ & $4-4.7(4.4)$ & $3.9-4.2(4.1)$ \\
\hline $\begin{array}{l}\text { Survival } \\
\text { rate (\%) }\end{array}$ & $80 \pm 5$ & $85 \pm 3$ & $87 \pm 3$ & $90 \pm 2$ & $97 \pm 1$ \\
\hline FCR & $1.1-1.3$ & - & $1.3-1.7$ & $0.6-1.3$ & $0.6-1.4$ \\
\hline $\mathrm{k}\left(\mathrm{d}^{-1}\right)$ & $0.04 \pm 0.01^{\mathrm{b}}$ & $0.019 \pm 0.01^{\mathrm{a}}$ & $0.04 \pm 0.01^{\mathrm{b}}$ & $0.044 \pm 0.01^{\mathrm{b}}$ & $0.041 \pm 0.01^{\mathrm{b}}$ \\
\hline $\mathrm{m}\left(\mathrm{d}^{-1}\right)$ & $0.18 \pm 0.01^{\mathrm{b}}$ & $0.075 \pm 0.04^{\mathrm{a}}$ & $0.17 \pm 0.03^{\mathrm{b}}$ & $0.24 \pm 0.04^{\mathrm{c}}$ & $0.21 \pm 0.01^{\mathrm{b}, \mathrm{c}}$ \\
\hline $\mathrm{t}_{50}(\mathrm{~d})$ & $2.8-3.6(3.1)$ & $8.1-15(11)$ & $2.5-4(3.3)$ & $1.2-3.7(2.4)$ & $2.4-3.1(2.7)$ \\
\hline$\delta^{15} \mathrm{~N}(\%)$ & $7.71 \pm 0.42$ & $8.82 \pm 0.30$ & $8.36 \pm 0.39$ & $8.23 \pm 0.38$ & $8.01 \pm 0.26$ \\
\hline$\delta^{15} \mathrm{Ng}(\%)$ & $7.70 \pm 0.46$ & $10.95 \pm 1.2$ & $8.73 \pm 0.43$ & $8.44 \pm 0.38$ & $8.15 \pm 0.27$ \\
\hline $\begin{array}{l}\text { Relative } \\
\text { contribution } \\
(\%)\end{array}$ & $7-32(16)$ & 100 & - & $5-29(10)$ & $16-38(18)$ \\
\hline
\end{tabular}

Different superscripts indicate significant differences $(a<b<c)$.

Table 5: Mean final weight, specific growth rate (SGR) and growth parameters ( $m$ and $k$ ), survival, feed conversion ration (FCR), natural stable isotope value $\left(\delta^{15} \mathrm{~N}\right)$ and estimated $\mathrm{N}$ half time $\left(\mathrm{t}_{50}\right)$ in tissue of medium (initial weight, $2.79 \pm 0.26 \mathrm{~g}$ $\delta^{15} \mathrm{~N}=7.72 \pm 0.3 \%$ ) $L$. vannamei reared for 28-days with formulated feed (FF, Pellet 35), natural feed (NF) and 50:50 formulated+natural feeds as plankton+biofloc $\left(\delta^{15} \mathrm{~N}_{\mathrm{NF}}=6.7 \pm 0.83 \%\right)(\mathrm{FF}+\mathrm{NF})$ and plankton+bioflocs+benthos $\left(\delta^{15} \mathrm{~N}_{\mathrm{NF}}=7.54 \pm\right.$ $0.83 \%$ ) $(\mathrm{FF}+\mathrm{NF}+\mathrm{S})($ Trial 3$)$. Relative contribution of natural diet to the growth of specimens reared on $\mathrm{FF}+\mathrm{NF}$ and $\mathrm{FF}+\mathrm{NF}+\mathrm{S}$ treatments. Isotopic trophic enrichment $\left(\Delta^{15} \mathrm{~N}=\delta 15 \mathrm{~N}_{\text {shrimp }}-\delta^{15} \mathrm{~N}_{\mathrm{NF}}\right.$ or FF) was estimated in $2.12 \%$ or $\mathrm{NF}$ and $2.56 \%$ o for FF.

\begin{tabular}{|l|c|c|c|c|c|}
\hline Parameter & Shrimp pond & NF & FF & FF+NF & FF+NF+S \\
\hline $\begin{array}{l}\text { Mean final } \\
\text { weight }(g)\end{array}$ & $17.60 \pm 0.23^{\mathrm{a}}$ & - & $17.34 \pm 1.32^{\mathrm{a}}$ & $17.19 \pm 0.23^{\mathrm{a}}$ & $18.1 \pm 0.84^{\mathrm{a}}$ \\
\hline SGR & $1.8-3.9(3.0)$ & - & $2.0-4.1(2.7)$ & $2.0-3.2(2.9)$ & $2.0-4.1(3.1)$ \\
\hline $\begin{array}{l}\text { Survival rate } \\
(\%)\end{array}$ & $74 \pm 2^{\mathrm{a}}$ & - & $93 \pm 3^{\mathrm{c}}$ & $87 \pm 5^{\mathrm{b}}$ & $90 \pm 3^{\mathrm{b}, \mathrm{c}}$ \\
\hline $\mathrm{FCR}$ & $1.1-1.3$ & - & $1.3-1.7$ & $0.7-1.3$ & $0.8-1.4$ \\
\hline $\mathrm{k}(\mathrm{d}-1)$ & $0.030 \pm 0.00^{\mathrm{a}}$ & - & $0.029 \pm 0$. & $0.03 \pm 0.00^{\mathrm{a}}$ & $0.031 \pm 0.01^{\mathrm{a}}$ \\
\hline $\mathrm{m}(\mathrm{d}-1)$ & $0.325 \pm 0.01^{\mathrm{a}}$ & - & $0.318 \pm 0.04^{\mathrm{a}}$ & $0.314 \pm 0.01^{\mathrm{a}}$ & $0.34 \pm 0.02^{\mathrm{a}}$ \\
\hline $\mathrm{t} 50(\mathrm{~d})$ & $1.9-2.2(2.0)$ & - & $1.8-2.3(2.0)$ & $1.7-2.7(2.0)$ & $1.8-2.0(1.9)$ \\
\hline$\delta_{15} \mathrm{~N}(\%)$ & $8.42 \pm 0.30$ & - & $8.23 \pm 0.17$ & $7.91 \pm 0.45$ & $7.61 \pm 0.81$ \\
\hline$\delta_{15} \mathrm{~N}(\%)$ & $8.81 \pm 0.33$ & - & $8.52 \pm 0.19$ & $8.02 \pm 0.50$ & $7.56 \pm 0.87$ \\
\hline $\begin{array}{l}\text { Relative } \\
\text { contribution(\%) }\end{array}$ & 0 & - & - & $<10$ & $9-16(13)$ \\
\hline
\end{tabular}

Different superscripts indicate significant differences $(a<b<c)$.

Table 6: Mean final weight, specific growth rate (SGR) and growth parameters ( $m$ and $k)$, survival, feed conversion ration (FCR), natural stable isotope value $\left(\delta^{15} \mathrm{~N}\right)$ and estimated $\mathrm{N}$ half time $\left(\mathrm{t}_{50}\right)$ in tissue of large (initial weight, $6.21 \pm 0.72 \mathrm{~g}, \delta^{15} \mathrm{~N}=6.95$ $\pm 0.34 \%$ ) L. vannamei reared for 35 -days with formulated feed $\left(F F, \delta^{15} \mathrm{~N}=5.8 \%\right.$ ), natural feed (NF) and 50:50 formulated+natural feeds as plankton+bioflocs (FF, $\delta^{15} \mathrm{~N}_{\mathrm{NF}}=6.7 \pm 0.83 \%$ o $)(\mathrm{FF}+\mathrm{NF})$ and plankton+bioflocs+benthos $\left(\delta^{15} \mathrm{~N}=6.81 \pm\right.$ $0.53 \%$ ) $(\mathrm{FF}+\mathrm{NF}+\mathrm{S})$ (Trial 4). Relative contribution of natural diet to the growth of specimens reared on $\mathrm{FF}+\mathrm{NF}$ and $\mathrm{FF}+\mathrm{NF}+\mathrm{S}$ treatments. Isotopic trophic enrichment $\left(\Delta^{15} \mathrm{~N}=\delta^{15} \mathrm{~N}_{\text {shrimp }}-\delta^{15} \mathrm{~N}_{\mathrm{FF}}\right)$ was estimated in $2.43 \%$ only for $\mathrm{FF}$. 
Citation: Bojórquez-Mascareño El, Soto-Jiménez MF (2013) Effects of Natural Diet on Growth on White-Leg Shrimp Litopenaeus vannamei Under Experimental Mesocosms Emulating an Intensive Culture System. J Aquac Res Development 4:163 doi:10.4172/2155-9546.1000163

Page 6 of 9

and ponds, except in NF treatments, where reached a maximum of $11 \mathrm{~d}$. The reduced growth of specimens in this treatment explained the elevated value of t50. FCR for specimens reared on FF+NF and $\mathrm{FF}+\mathrm{NF}+\mathrm{S}$ showed a minimum range of $0.6-1.4$, while $\mathrm{FF}$ treatment reached maximum values from 1.3 to 1.7 . Growth parameters measured in specimens reared on ponds were comparable to FF treatment. In trial 4 (Table 6), the larger specimens reared on NF did not showed growth and cannibalism was present, thus results were discarded. For the rest of treatments, the mean final weight (17.19-18.1 g), SGR (2.7$\left.3.1 \% \mathrm{~d}^{-1}\right), \mathrm{m}\left(0.314-0.340 \mathrm{~d}^{-1}\right)$ and $\mathrm{k}\left(0.029-0.031 \mathrm{~d}^{-1}\right)$ were not different among treatments and in ponds. Values for t50 ranged from 1.9 to $2 \mathrm{~d}$ among treatments and ponds. Similar FCR ranges (from 0.7-1.4) were observed for specimens reared on $\mathrm{FF}+\mathrm{NF}$ and $\mathrm{FF}+\mathrm{NF}+\mathrm{S}$, lower to those in FF treatment (1.3-1.7) and all lower to specimens in ponds (1.6-2.8).

Results of the isotopic composition in specimens reared on different treatment and trials are shown in tables $3-6 . \delta^{15} \mathrm{~N}$ values measured in the tested shrimp averaged from 8.19 to $12.0 \%$, 7.43 to $10.13 \%$, and 8.01 to $8.36 \%$ and from 7.61 to $8.23 \%$ on trials 1 to 4 , respectively. Significantly, differences were observed in $\delta^{15} \mathrm{~N}$ values in specimens at the end of experiments respect to those found at the beginning and with their diets $(\mathrm{p}<0.05)$. As expected, $\delta^{15} \mathrm{~N}$ values in specimens varied according to the signals in the different diets and those specimens reared on unique and constant diet were gradually reaching the isotopic equilibrium. This occurred in weeks 1-2 for post-larvae and 3-4 weeks in juveniles after the dietary switch. In the case of larger juveniles reared on NF diet, with low rates of growth and turnover, the equilibrium was not reached at the end of the experiments ( 7 weeks). Thus, NF treatment at trial 4 was discarded and non estimations of trophic shift were done. The trophic enrichment in $\delta^{15} \mathrm{~N}$ between shrimp and diets varied 2.03 to 2.49 and 1.90 to $2.56 \%$ of $\mathrm{NF}$ and FF, respectively. Non-differences in the $\Delta^{15} \mathrm{~N}$ were observed for specimens reared on natural diet compared to specimens reared with formulated diet, and although differences between $\delta^{15} \mathrm{~N}$ mean in shrimp and its diet was higher for postlarvae than for juveniles, the mean trophic shift was not significantly different ( $p>0.05$ ). Thus, we estimated a mean $\Delta^{15} \mathrm{~N}$ value of $+2.31 \pm 0.23 \%$. Isotopes data measured in specimens reared on combined diets were not considered to account the discrimination factor, but they were used to estimate the relative contribution in the muscle.

The availability of the different components of natural foods identified (e.g., phytoplankton, zooplankton, zoobenthos, bioflocs, and detritus) varied among trials and during experiments. Similar variations in the components of natural productivity were observed along the shrimp farm cycle. Assessing nutrient contribution of natural productivity to growth shrimp using stable isotopes is difficult due to the variations in the relative biomass and in the isotopic composition values of NF. An assumed prerequisite to resolve the isotopic mixing models is that each potential source has distinct values of $\delta^{15} \mathrm{~N}$. In our study most of the NF components had contrasting $\delta^{15} \mathrm{~N}$ values, but two of the most abundant showed very similar signals (e.g., detritus and microflocs) (Table 1). In this case, with non-significant differences between micro-flocs and detritus, resolving mixing models is limited due to the overlapping isotopic signals. In order to resolve this conflict we considered both dietary sources as one, and denominated it as benthos. Besides, the combination of phytoplankton, zooplankton and algae-floc in the water column was denominated plankton.

Based on $\mathrm{N}$ isotope mass balance of the available natural components in NF tanks and final $\delta^{15} \mathrm{~N}$ signals in shrimp, we estimated the contribution of the main components of the natural food diet in each trial. Results revealed that natural food was constituted by zooplankton
(70\%) and algae-floc and phytoplankton (30\%) for trial 1 (global average $\mathrm{NF}=9.8 \%$ ), by plankton $(26 \%)$ and benthos $(74 \%)$ for trial $2(\mathrm{NF}=8.13 \%$ ), and accounting 15 and $85 \%$ for trial $3(\mathrm{NF}=7.54 \%$ ), respectively. In trial 4 , practically $100 \%$ of the natural diet was composed by benthos $(\mathrm{NF}=6.81 \%$ ). The influence of the natural diet on a body weight of PL's and juveniles was also evaluated by using an isotopemixing model (Table 3). For PL20's at trial 1, the N contributions to growth of $\mathrm{NF}$ in specimens reared on $\mathrm{FF}+\mathrm{NF}$ and $\mathrm{FF}+\mathrm{NF}+\mathrm{S}$ treatments averaged from 18 to $74 \%$ and 25 to $62 \%$, respectively. In trials 2 to 4 , $\mathrm{N}$ contributions to growth ranged from $8-22 \%$ and $27-67 \%$ for small juveniles, $5-29 \%$ and $16-38 \%$ for medium juveniles and $<10 \%$ and 9-16\% for larger juveniles, respectively. In ponds, the NF contributions to growth shrimp varied also with the size of the specimens, from 52$78 \%$ for PL20's, $6-32 \%$ in small and medium juveniles, to negligible for larger juveniles. The wide variability in the isotopic values of specimens reared on the different diets at the end of the experiment resulted in a wide range of contribution percentages. However, significant differences $(\mathrm{P}<0.001)$ were detected in the $\mathrm{N}$ contribution in function of size (postlarvae>small and medium juveniles> larger juveniles) and treatment $(\mathrm{NF}+\mathrm{FF}+\mathrm{S}>\mathrm{NF}+\mathrm{FF})$. The accumulated biomass gains (estimated as the averaged weight $\mathrm{x}$ survival percentage) observed in each treatment compared to the pond specimens of the same size ranges, was accounted in $4-26 \%$ for FF, $13-26 \%$ for $\mathrm{FF}+\mathrm{NF}$ and $19-31 \%$ for $\mathrm{FF}+\mathrm{NF}+\mathrm{S}$ treatments.

\section{Discussions}

Because the variability in shrimp growth is influenced by a range of biotic and abiotic factors [31], in this study factors such as temperature, salinity, oxygen concentration, and $\mathrm{pH}$ were similar among treatments and ponds. However, the concentration of TN and their chemical forms varied in trials and along the culture cycle, related to the size of the organisms and feeding rates.

At the end of the experiments, survival rates and growth (e.g., final weight, weight gain and SGR of the shrimp reared on combined diet treatments were comparable (trial 3 and 4 ) or even better (trials 1 and 2) than those reared on pure diet. The FCR values were lower in combined diet than in FF treatments. The growth's parameters and FCR measured over the same periods in the farm ponds were comparable to those observed in the experimental mesocosms. Particularly, the NF+FF+S treatment. However, the survival rates in ponds (70-85\%) were lower than those in experiments $(>90 \%)$, thus the biomass performance was higher on experimental trials than ponds. Better environmental conditions in the trials could explain a higher performance on trials than ponds.

The rapid growth of PL and small juveniles (fed on pure and combined diets) allows them to achieve isotopic equilibrium ( $t 50<5 \mathrm{~d})$ within the experimental periods ( 11 to $35 \mathrm{~d}$ ). The isotopic fractionation between equilibrated animal tissue and diet ranged from 1.9 to $2.56 \%$, without distinction among trials (sizes) and treatments (pure diets). Previous experiments have demonstrated that 5 to $15 \mathrm{~d}$ is the time period to reach isotopic equilibriums between L.vannamei and their constant diets and $\Delta^{15} \mathrm{~N}$ values in the same range [23]. However, these authors found differences between diets related to the protein content (0. 8-3.6\%o and 1.1-5.0\%o for 46 and $23 \%$ crude protein diets, respectively) and the sizes (0.8-5.0\% in postlarval shrimp and 1.3$7.8 \%$ in juvenile shrimp) concluding that discrimination factors are influenced by shrimp's age, dietary protein level and type of ingredients used in the diets. In this study, we considered that both FF and NF diets (roughly isonitrogenous) showed comparable nutritional quality (e.g., 
Citation: Bojórquez-Mascareño El, Soto-Jiménez MF (2013) Effects of Natural Diet on Growth on White-Leg Shrimp Litopenaeus vannamei Under Experimental Mesocosms Emulating an Intensive Culture System. J Aquac Res Development 4:163 doi:10.4172/2155-9546.1000163

Page 7 of 9

$\mathrm{C}: \mathrm{N}$ of $4.65-7.65$ and $7.6-8.51$, respectively) resulting in comparable $\Delta^{15} \mathrm{~N}$ values $[32,33]$

Based on the results from the four growth trials, we accounted the contributions of the natural productivity regulating growth rates and performance of the animals, which varied among trials and culture time, decreasing with size of shrimp. Analysis of postlarval and small juvenile muscle tissue reared on combined diets and ponds indicated a major contribution of natural productivity the PL20's growth (accounting over 50\%), and then for small and medium juveniles (accounting 15$31 \%$ and $16 \%$ for, respectively). NF contribution for larger specimens (trial 4) was significantly lower $(<10$ to $13 \%)$, while in the ponds it was negligible. Natural productivity did not appear to be a significant contributor to the growth and nutrition of larger juveniles; however, not enough NF throughout the experimental days, both tanks and ponds, explains its low contribution. Even cannibalistic behavior of shrimps was observed in the NF treatment in trial 4 , thus results were discarded. Most studies of the contribution of NF to shrimp growth using natural abundances of stables isotopes have been expressed in terms of $\mathrm{C}$ whiting semi-intensively reared pondraised shrimp $[1,34,35]$. These studies have found that between 44 and $86 \%$ of the shrimp growth can be due to pond natural productivity. Few studies have reported NF contributions in terms of $\mathrm{N}$ emulating intensive growth-out ponds. One of the most representative was carried out [24] in experimental mesocosms with medium juveniles $L$. vannamei $\left(50 \mathrm{~m}^{-2}\right.$, initial weight of $3.5 \mathrm{~g}$ ) in zero water exchange outdoor. Authors revealed that the NF contributions were up to the $28-31 \%$. Following similar methodological strategies, Bufford et al. [36] estimated a natural contribution (by bioflocs) to the nutrition of $L$. vannamei from $18 \%$ to $29 \%$ for 1 to $9 \mathrm{~g}$ animals. Ranges of contribution are comparable with our results on trial 3 (initial weight of $2.79 \mathrm{~g}$ ), where the contributions account a $5-29 \%(10)$ and $16-38 \%(18)$ in $\mathrm{NF}+\mathrm{FF}$ and $\mathrm{NF}+\mathrm{FF}+\mathrm{S}$ treatments.

\section{Components of the natural productivity}

In a typical earth pond shrimp farm, the natural foods are present in different forms [37-42], which were evidenced in our observations. $L$. vannamei are capable of selecting specific prey items from the mixture of natural components available in the water column and sediments, as it occurs in natural systems for Penaeid shrimp [43]. In fact, microscopical analysis of shrimp gut content on culture earth ponds have revealed the presence of a large variety of food items in addition to the commercial feed, including detritus, nematodes, copepods, amphipods, polychaetes, bivalves, and diatoms [1,7-9,38-40].

Based on our observations, the availability of the NF components (e.g., plankton, benthic organisms, flocs, and detritus) changed among trials and ponds along the cycle, in response to the management practices (e.g., FR, WER), environmental conditions and nutrient concentrations $[31,41,42]$. For a species that feeds opportunistically or exhibits rapid ontogenetic changes, such as $L$. vannamei, the manipulations occurring in the diet during the culture time, may result in a large isotopic variance among individuals, partially or completely depending on natural diet. In fact, changes in the isotopic data were detected, being higher in specimens using natural components than those reared on FF (unique and constant diet).

Isotopic data in shrimp muscle were used to reconstruct the natural diet of L. vannamei in treatments with combined diets in each trial and ponds integrating the changes in the food sources along the culture cycle. Based on the results, L. vannamei postlarvae grew by feeding on zooplankton, which obtained their nutrition from phytoplanktonderived organic matter. In the presence of sediment and detritus associated, postlarvae probably consumed micro-flocs (microbial aggregates) found in detritus. However, the relative importance of benthonic nutrition to postlarva was lower than planktonic nutrition. Postlarvae were enriched by 2.2 and $5.1 \%$ in $\delta^{15} \mathrm{~N}$ relative to the zooplankton and phytoplancton, respectively. This isotopic fractionation reflects a two level trophic food-chain: phytoplankton<zo oplankton $<$ shrimp postlarvae.

The contribution of the zooplankton diet declined with the shrimp size while the dependence for benthic nutrition (detritus-based foodweb) increased. For small juveniles, the isotopic signal of the specimens reared on NF diet indicates that zooplankton and benthonic foods accounted 25 and $75 \%$, respectively, while for medium and larger juveniles it was only benthonic. The detritus-based food-web was constituted by micro-flocs and benthic fauna (e.g., meiofauna and polychaetes). Isotopic data revealed that shrimp did not utilize the detritus directly, but they selectively picked preys from the detritus mixture as reported in natural ecosystems [43]. Although detritus may provide specific nutrients that promote higher survival, the low nutritional quality (e.g., high $\mathrm{C}: \mathrm{N}$ ratio) and low digestibility limits its contribution to the tissue growth. The $\delta^{15} \mathrm{~N}$ values in the NF treatment imply that there are two trophic links between the detritus (4.81\%o) and the shrimp (10.13\%o).

The dependence of NF gradually decreased in juveniles reared on combined diet treatments and in ponds, while the dependence of FF accounted practically $100 \%$ for larger juveniles. The voracity of $L$. vannamei and the reduced availability of natural productivity explain the drastic reduction in its importance as a contributor. Lack of benthic fauna (few meiofaunal organisms and absence of polychaetes) explains the null contribution of NF diet to larger juveniles reared on NF treatment and in ponds. Even, serious implications in the growth and survival rates of specimens were observed in trial 4 when NF components were scarce.

Despite the reduction of the $50 \%$ of the FF in the combined diet treatment regarding the FR applied at the farm level, most trials showed enough nutrients to sustain the phytoplankton and detritus-based foodwebs in the water column and sediments, respectively. The degradation of the excess of FF supplied the necessary nutrients to promote the natural productivity resulting in non-differences in the growth respect to the $100 \% \mathrm{FF}$ diet treatment and in ponds.

\section{Implications}

About $16.7 \%$ (by dry weight) of the total FF applied to the pond is converted into shrimp biomass [27], but most of the non-ingested and no-assimilated particles of the FF pellets are accumulated in the sediments and disintegrated in few hours and one part of deposited particles are eventually decomposed in few days. In Aquastrat, we estimated that only the $14-16 \%$ of the FF was recovered in biomass in both cycles, most of FF is eliminated as particulate organic matter and dissolved metabolites via effluents and a small fraction remains in sediments. Excessive amounts of FF-derived organic matter increase during the culture time and result in loss of water and sediment quality affecting the availability and quality of natural food. Besides the accumulation of feed waste results in hypoxia or anoxia events and in black soil formation, which affects the cultured organism's life but also in terms of commercial qualities (e.g., bad appearance by black gills) and then the market price? The only solution applied in the shrimp farm with intensive culture system is increasing the water exchange, for example, in Aquastrat the water pond is renewed close to 200 times per cycle $\left(\sim 30 \mathrm{~m}^{3}\right.$ of seawater per kilogram of shrimp). 
Citation: Bojórquez-Mascareño El, Soto-Jiménez MF (2013) Effects of Natural Diet on Growth on White-Leg Shrimp Litopenaeus vannamei Under Experimental Mesocosms Emulating an Intensive Culture System. J Aquac Res Development 4:163 doi:10.4172/2155-9546.1000163

However, this common practice in farms with intensive culture systems increases the operation cost (excess of FF, pumping and mechanical aeration energy) and the environmental impact to the adjacent coastal ecosystems receiving effluents (organic matter, nutrients and many other deleterious substances).

According to our results, an adequate combination of formulated feed ( $50 \%$ of the actual FR) and promotion of the natural productivity enhance the growth and development of PL's to smaller juveniles. Based on a weight and growth rates evaluation and SIA, the natural diet is a good complement to sustain the growth of post-larvae and juveniles at least during the first 5 weeks of the culture. After week 5, maintaining the proper grow of juveniles L. vannamei is achieved with exclusive use of formulated feed following better management techniques, for example using control systems such feeding trays [15].

Because the results were based on experimental mesocosms under the conditions of an intensive culture and we included a followed study in representative earth ponds, it is possible to extrapolate them to a farm level. This suggests that during the first 2-3 weeks of shrimp farm intensive culture, in the postlarvae stage, the significant amounts of artificial feed added to the ponds are converted in natural production. Promoting the availability of feed sources other than commercial feeds can markedly improve the growth and production of cultured shrimp, while reducing FCRs and consequently the use of commercial food. If natural food items are abundant in the culture water following an adequate fertilization and management of the water quality and sediments, farmers may be able to reduce feed inputs and allow shrimp to rely slightly more on pond primary productivity to reduce FCRs and improve profitability.

Aquaculture in Mexico and around the world should be used to maximize the natural resources in ponds. Particularly, an adequate FF management in the shrimp farms results in economic benefits, less affectation of production systems and minimizes the pollution in receiving natural ecosystems. Following this strategy, a significant reductionf formulated feed can be viable in intensive culture systems by promoting natural food production in ponds, with a consequent reduction of the operation costs and the environmental impact.

\section{Acknowledgements}

The authors would like to thank the directives and personnel of Granja Aquastrat for their support for this research, also thanks to $\mathrm{H}$. Bojórquez-Leyva, S. Rendón-Rodriguez and A. Nuñez-Pastén for their invaluable assistance in the field and laboratory work, and V. Montes and Y. Montaño-Ley for their support in the preparation of this manuscript. Financial support was provided by the grant SEP-CONACYT 60215.

\section{References}

1. Anderson RK, Parker PL, Lawrence $A A(1987) A{ }^{13} C /{ }^{12} C$ tracer study of the utilization of presented feed by a commercially important shrimp Penaeus vannamei in a pond grow out system. J World Aquaculture Society 18: 148-155.

2. Chamberlain GW (1995) Frontiers in Shrimp Nutrition Research. In: Browdy CL, Hopkins JS (Eds ) Swimming Through Troubled Water. The World Aquaculture Society, Baton Rouge, LA, 108-117.

3. Jory DE (1995) Management of natural productivity in marine shrimp semi intensive ponds. Aquaculture Magazine 21: 90-100.

4. Martinez-Cordova LR, Porchas-Cornejo MA, Villarreal-Colemnares $\mathrm{H}$ Calderon- Perez JA, Naranjo-Paramo J (1998) Evaluation of three feeding strategies on the culture of white shrimp Penaeus vannamei Boone, 1931 in low water exchange ponds. Aquaculture Engineering 1: 21-28.

5. Sangha RS, Puello-Cruz A, Chávez-Sánchez MC, Jones DA (2000) Survival and growth of Litopenaeus vannamei (Boone) larvae fed a single dose of live algae and artificial diets with supplements. Aquaculture Research 31: 683-689.
6. Lavens P, Sorgeloos P (2000) Experiences on importance of diet for shrimp post larval quality. Aquaculture 191: 169-176.

7. Soares R, Peixoto S, Wasielesky W, D'Incao F (2005) Feeding rhythms and diet of Farfantepenaeus paulensis under pen culture in Patos Lagoon estuary, Brazil. Journal of Experimental Marine Biology and Ecology 322: 167-176.

8. Martinez-Córdova LR, Campaña-Torres A, Porchas-Cornejo MA (2003) Dietary protein level and natural food management in the culture of blue (Litopenaeus stylirostris) and white shrimp (Litopenaeus vannamei) in microcosms. Aquaculture Nutrition 9:155-160.

9. Soares R, Peixoto S, Bemvenuti C, Wasielesky W, D'Incao F, et al. (2004) Composition and abundance of invertebrate benthic fauna in Farfantepenaeus paulensis culture pens (Patos Lagoon estuary, southern Brazil). Aquaculture 239: 199- 215.

10. Decamp O, Conquest L, Forster I, Tacon AGJ (2002) The nutrition and feeding of marine shrimp within zero-exchange aquaculture production systems: role of Eukaryotic microorganisms. In: Lee CS, O’Bryen P (Eds) Microbial approaches to aquatic nutrition within environmentally sound aquaculture production systems. World Aquaculture Society, Baton Rouge, LA, 79-86.

11. Browdy CL, Moss SM (2005) Shrimp Culture In Urban, Superintensive Closed Systems. In: Costa Pierce BA (Eds ) Urban Aquaculture. Blackwell Science, Oxford UK, 173-186

12. Wasielesky W, Atwood H, Stokes A, Browdy CL (2006) Effect of natural production in a zero exchange suspended microbial floc based super-intensive culture system for white shrimp Litopenaeus vannamei. Aquaculture 258: 396 403.

13. Jory DE (2001) Feed management practices for a healthy pond environment In: Browdy CL, Jory, DE (Eds) The new wave. Proceedings of the Special Session on Sustainable Shrimp Culture. World Aquaculture Society, Baton Rouge, LA, 118-143.

14. Smith DM, Burfod MA, Tabrett SJ, Irvin SJ, Ward L (2002) The effect of feeding frequency on water quality and growth of the black tiger shrimp (Penaeus monodon). Aquaculture 207: 125-136.

15. Casillas-Hernández R, Nolasco-Soria H, García-Galano T, Carrillo-Farnes O Páez-Osuna $F$ (2007) Water quality, chemical fluxes and production in semiintensive Pacific white shrimp (Litopenaeus vannamei) culture ponds utilizing two different feeding strategies. Aquaculture Engineering 36: 105-114

16. Quintero HE, Roy LA (2010) Practical feed management in semi- intensive systems for shrimp culture. In: Alday-Sanz V (Eds ) The shrimp book. Nottingham University Press, Nottingham, UK, 443-454.

17. Moss SM, Pruder GD (1995) Characterization of organic particles associated with rapid growth in juvenile white shrimp, Penaeus vannamei Boone, reared under intensive culture conditions. J Exper Mar Biol Ecol 187: 175-191.

18. Tacon AGJ, Cody JJ, Conquest LD, Divakaran S, Forster IP, et al. (2002) Effect of culture system on the nutrition and growth performance of Pacific white shrimp Litopenaeus vannamei (Boone) fed different diets. Aquaculture Nutrition 8: 121-137.

19. Roy LA, Allen DD, Whitis GN (2012) Effect of feeding rate and pond primary productivity on growth of Litopenaeus vannamei reared in inland saline waters of west Alabama. North American Journal of Aquaculture 74: 20-26.

20. Wu JX, Lu QP (2012) Effects of bioflocs on growth performance, digestive enzyme activity and body composition of juvenile Litopenaeus vannamei in zero-water exchange tanks manipulating $\mathrm{C} / \mathrm{N}$ ratio in feed. Aquaculture 356 357: $147-152$

21. Preston NP, Smith DM, Kellaway DM, Bunn SE (1996) The use of enriched $15 \mathrm{~N}$ as an indicator of the assimilation of individual protein sources from compound diets for juvenile Penaeus monodon. Aquaculture 147: 249-259.

22. Burford MA, Preston NP, Glibert M, Dennison WC (2002) Tracing the fate of $15 \mathrm{~N}$-enriched feed in an intensive shrimp system. Aquaculture 206: 199-216.

23. Gamboa-Delgado J, Le Vay L (2009) Natural stable isotopes as indicators of the relative contribution of soy protein and fish meal to tissue growth in Pacific white shrimp (Litopenaeus vannamei) fed compound diets. Aquaculture 291 $115-123$

24. Epp MA, Ziemann DA, Schell DM (2002) Carbon and Nitrogen dynamics in zero-water exchange shrimp culture as indicated by stable isotope tracers Aquaculture Research 33: 839-846. 
Citation: Bojórquez-Mascareño El, Soto-Jiménez MF (2013) Effects of Natural Diet on Growth on White-Leg Shrimp Litopenaeus vannamei Under Experimental Mesocosms Emulating an Intensive Culture System. J Aquac Res Development 4:163 doi:10.4172/2155-9546.1000163

Page 9 of 9

25. Grasshoff K, Ehrhardt K, Kremling K (1983) Methods of seawater analysis. Verlag Chemie, Weinheim, New York, USA.

26. Solorzano L, Sharp JH (1980) Determination of total dissolved nitrogen in natural waters. Limnology and Oceanography 25: 751-754.

27. Hasan BMA, Guha B, Datta S (2012) Optimization of Feeding Efficiency in Semi-Intensive Farming System for Sustainable and Cost Effective Production of Penaeus monodon Fabricius. J Aquacult Res Dev 3: 149.

28. Hesslein RH, Hallard KA, Ramlal P (1993) Replacement of sulfur, carbon, and nitrogen in tissue of growing broad whitefish (Coregonus nasus) in response to a change in diet traced by $34 \mathrm{~S}, 13 \mathrm{C}$, and $15 \mathrm{~N}$. Can J Fish Aquat Sci. 50: 2071-2076.

29. Phillips DL, Gregg JW (2001) Uncertainty in source partitioning using stable isotopes. Oecologia 127: 171-179.

30. Zar J (1984) Biostatistical análisis. Prentice-Hall. (2ndedn), New Jersey. 718.

31. Tacon AGJ (2002) Thematic review of feed and feed management practices in shrimp aquaculture. A Report for FAO, World Bank, WWF, and NACA. Aquatic Farms Ltd.,Kanehoe, HI.

32. Le Vay L, Gamboa-Delgado J (2011) Naturally-occurring stable isotopes as direct measures of larval feeding efficiency, nutrient incorporation and turnover. Aquaculture 29: 95-103.

33. Martínez del Rio C, Wolf BO (2005) Mass-balance models for animal isotopic ecology. In: Starck JM, Wang T (Eds) Physiological and Ecological Adaptations to Feeding in Vertebrates, Science Publishers, Enfield, NH, pp: 141-174 .

34. Nunes AJP, Gesteira TCV, Goddard S (1997) Food consumption and assimilation by the Southern brown shrimp Penaeus subtilis under semiintensive culture in NE Brazil. Aquaculture 149: 121-136.

35. Parker PL, Anderson RK, Lawrence A (1989) A d13C and d15N tracer study of nutrition in Aquaculture: Penaeus vannamei in a pond grow-out system. In: Rundel PW, Ehleringer JR, Nagy KA (Eds) Stable Isotopes in Ecological Research. Springer-Verlag, New York, 288-303.

36. Burford MA, Thompson PJ, McIntosh RB, Bauman RH, Pearson DC (2004) The contribution of flocculated material to shrimp (Litopenaeus vannamei) nutrition in a highintensity, zero-exchange system. Aquaculture 232: 525-537.

37. Reymond H, Lagardère JP (1990) Feeding rhythms and food of Penaeus japonicus Bate (Crustacea, Penaeidae) in salt-water ponds: role of halophilic entomofauna. Aquaculture 81:125-143.

38. Newell RIE, Marshall N, Sasekumar A, Chong VC (1995) Relative importance of benthic microalgae, phytoplankton, and mangroves as sources of nutrition for penaeid prawns and other coastal invertebrates from Malaysia. Marine Biology 123: 595-606.

39. Tidwell JH, Coyle SD, Webster CD, Sedlacek JD, Weston PA, et al. (1997) Relative prawn production and benthic macroinvertebrate densities in unfed, organically fertilized, and fed pond systems. Aquaculture 149: 227-242.

40. Focken U, Groth A, Coloso R, Becker K (1998) Contribution of natural food and suplemental feed to the gut content of Penaeus monodon Fabricius in semiintensive pond system in the Phillipines. Aquaculture 164: 105-116.

41. Allan GL, Maguire GB (1992) Effects of stocking density on production of Penaeus monodon Fabricius in model farming ponds. Aquaculture 107: 49-66.

42. Allan GF, Moriarty DJW, Maguire GB (1995) Effects of pond preparation and feeding rate on production of Penaeus monodon Fabricius, water quality, bacteria, and benthos in model farming ponds. Aquaculture 130: 329-349.

43. Dittel I, Epifanio CE, Cifuentes LA, Kirchman DL (1997) Carbon and nitrogen sources for shrimp postlarvae fed natural diets from a tropical mangrove system. Estuarine, Coastal and Shelf Science 45: 629-637. 